\title{
PENGALAMAN REMAJA DALAM MENGIMPLEMENTASIKAN PUASA SEBAGAI PEMBENTUK KEPRIBADIAN (STUDI TERHADAP REMAJA MASJID JAMI' AL-MUHARRAM DI DESA BANDAR KHALIPAH)
}

\author{
Anas Munandar Matondang \\ Universitas Muhammadiyah Tapanuli Selatan \\ Email: anasmunandarbk@gmail.com
}

\begin{abstract}
ABSTRAK
Adapun yang menjadi latar belakang penelitian ini adalah, bahwa secara umum remaja melaksanakan puasa wajib (ramadhan). Akan tetapi puasa yang mereka lakukan dari tahun ke tahun belum ada efeknya terhadap perubahan prilaku mereka sehari-hari. Selama puasa mereka masih suka mengucapkan kata-kata kotor, mengejek dan menghina kawan sendiri, mencuri, main judi, minum-minuman, menonton film porno, pergaulan bebas (pacaran), melawan orang tua, keterlibatan obat-obatan (Narkoba) dan lain sebagainya yang mengakibatkan puasa yang mereka kerjakan tidak berdampak pada perubahan perilakunya. Jenis penelitian yang digunakan adalah field research (penelitian lapangan) dengan menggunakan metode kualitatif. Hakikat peneliti sebagai instrumen kunci diaplikasikan dalam penggunaan teknik pengumpulan data kualitatif yang terdiri dari observasi berperanserta dan wawancara. Aalisis data dibagi menjadi tiga tingkat, yaitu analisis data pada tingkat awal, analisis pada saat pengumpulan data lapangan dan analisi data setelah selesai pengumpulan data dan terakhir adalah triangulasi data. Hasil yang dipeoleh dalam penelitian ini yaitu pertama saudara Angga advori Pratama memiliki pengalaman bahwa puasa berdampak positif terhadap pembentukan kepribadiannya. Kedua Anggi Putri Dewi memiliki pengalaman bahwa puasa berdampak positif terhadap pembentukan kepribadiannya. Ketiga Hermansyah Piliang memiliki pengalaman bahwa puasa belum berdampak apapun terhadap kepribadiannya dan terakhir saudara Ridwan memiliki pengalman belum dapat merasakan hikmah dari puasa terutama terhadap pembentukan kepribadiannya. Saran saya untuk mengatasi kendala-kendala dan problema yang dihadapi oleh remaja dalam melaksanakan puasa akan dapat teratasi apabila ada kerjasama yang dibangun antara orang tua dengan pemuka agama, antara orang tua dengan remaja, antara remaja dengan pemuka agama dan kerjasama antara remaja dengan masyarakat.
\end{abstract}

Kata Kunci : Remaja, Puasa, Kepribadian

\section{ADOLESCENT EXPERIENCES DRIVER MAKES FAST AS A PERSONAL FORMER (STUDY ON TEACHERS OF ADMINISTRATION, 'AL-MUHARRAM IN BANDAR KHALIPAH VILLAGE)}

\begin{abstract}
The background of this research is that in general adolescents carry out compulsory fasting (ramadhan). But the fast that they do from year to year has no effect on their daily behavior changes. During fasting they still like to say dirty words, ridicule and insult their friends, steal, play gambling, drink, watch porn, promiscuity (dating), fighting parents, involvement of drugs (drugs) and others that cause fasting they do not have an impact on changes in behavior. The type of research used is field research using qualitative methods. The nature of the researcher as a key instrument was applied in the use of qualitative data collection techniques which consisted of observations of participation and interviews. Data analysis is divided into three levels, namely data
\end{abstract}


analysis at the initial level, analysis at the time of field data collection and data analysis after completion of data collection and finally data triangulation. The results obtained in this study are first brothers Angga Pratama advocates have experience that fasting has a positive impact on the formation of his personality. Second Anggi Putri Dewi has experience that fasting has a positive impact on the formation of her personality. Third Hermansyah Piliang has experience that fasting has not had any impact on his personality and finally brother Ridwan has a pengalman not yet able to feel the wisdom of fasting especially towards the formation of his personality. My suggestion to overcome the constraints and problems faced by adolescents in carrying out fasting can be overcome if there is cooperation built between parents and religious leaders, between parents and teenagers, between adolescents with religious leaders and cooperation between adolescents and the community.

\section{Keywords: Teenagers, Fasting, Personality}

\section{PENDAHULUAN}

Berdasarkan survey awal yang peneliti lakukan di desa Bandar Khalipah Dusun I dan II Kecamatan Percut Sei Tuan Kabupaten Deli Serdang terhadap pelaksanaan ibadah puasa Ramadhan $1432 \mathrm{H}$, terlihat bahwa secara umum remaja melaksanakan puasa wajib (ramadhan). Akan tetapi puasa yang mereka lakukan dari tahun ke tahun belum ada efeknya terhadap perubahan prilaku mereka seharihari. Selama puasa mereka masih suka mengucapkan kata-kata kotor, mengejek dan menghina kawan sendiri, mencuri, main judi, minum-minuman, menonton film porno, pergaulan bebas (pacaran), melawan orang tua, keterlibatan obatobatan (Narkoba) dan lain sebagainya. Mereka menjalani puasa hanya sekedar rutinitas saja tidak berdasarkan ilmunya, ada yang melaksanakan puasa karena takut kepada orang tuanya, dan ada juga karena di suruh guru di sekolah dan mengisi laporan tentang puasa yang di laksanakannya, ada yang berpuasa tapi tidak melaksanakan shalatnya, ada yang berpuasa tapi pada malam hari bukannya tarawih tetapi pergi bersenang-senang ke pusat keramaian mencari makanan dan kesenangan, dan yang lebih memprihatinkan lagi adalah kebiasaan remaja pada umumnya, remaja masjid Jami' Al-Muharram khususnya di desa ini setelah selesai sahur mereka pergi jalan-jalan beramai-ramai dengan membonceng pacarnya ataupun perempuan yang merupakan lawan jenisnya yang di kenal dengan istilah kerennya asmara subuh. Padahal mereka baru saja melaksanakan sahur dan belum mengerjakan sholat subuh. 
Disisi lain penulis juga mengumpulkan data awal terhadap pelaksanaan puasa wajib dengan mewawancarai orang tua remaja. Diketahui secara umum anak remaja mereka tetap melaksanakan puasa, khususnya puasa ramadahan di samping puasa-puasa sunnah. Informasi yang di dapatkan tentang pelaksanaan puasa wajib ini sangat beragam. Pada keluarga yang ketaatannya pada agama cukup baik, maka frekuensi pelaksanaan puasa wajib remaja yang ada pada keluarga tersebut tinggi. Sebaliknya keluarga yang tingkat ketaatan beragamanya rendah, frekuensi remaja yang ada pada keluarga tersebut dalam melaksanakan puasa wajib adalah rendah.

Dilihat dari segi kepribadian remaja di desa Bandar Khalipah, pada umumnya kurang baik. Indiakasi kurang baiknya kepribadian remaja terlihat dari prilaku yang mereka tampilkan dalam kehidupan sehari-hari. Remaja terlibat dalam berbagai bentuk kejahatan dan mereka juga hanya melaksanakan puasa bukan karna kesadaran sendiri. Berbagai bentuk perjudian, berkelahi, mengisap ganja, minum-minuman keras, dan pergaulan bebas dan perzinahan dalam bentuk berpacaran. Akhirnya pergaulan bebas ini seringkali berdampak pada perkawinan dini bagi remaja. Pasangan remaja putra dan putri harus segera di nikahkan karena remaja putrinya sudah hamil sebelum menikah secara resmi.

Apabila ditelusuri rendahnya frekuensi pelaksanaan puasa wajib remaja, tentunya relevan dengan buruknya kepribadian remaja. Padahal Remaja sebagai salah satu aset keluarga, bangsa, negara bahkan agama, merupakan suatu generasi yang menjadi ujung tombak bagi suksesnya peradaban, oleh karena itu perlu bagi remaja nilai akhlak, pengetahuan, dan keimanan, salah satu konsep untuk meningkatkan itu adalah puasa. Puasa sebagai sarana ibadah wajib terkadang dipahami hanya sebagai ritual menahan lapar dan dahaga semata tanpa menyadari manfaat yang kausalitas bahwa manfaat puasa itu penting bagi peningkatan nilainilai tersebut.

Adapun tujuan diadakannya penelitian ini adalah Untuk mengetahui pengalaman Remaja Masjid Jami' Al-Muharram dalam mengimplementasikan puasa sebagai pembentuk kepribadiandi Desa Bandar Khalipah Dusun I dan II Kecamatan Percut Sei Tuan Kabupaten Deli Serdang. 
Menurut Muhammad Idrus (2001:60-61) Fakultas Dakwah IAIN Sumatera Utara dengan judul "Fungsi Puasa Bagi Kesehatan Mental Menurut Zakiah Daradjat".Menurut Muhammad Idrus bahwa inti dari perintah menjalankan puasa adalah pengendalian diri (self control).Pengendalian diri adalah salah satu ciri utama bagi mental yang sehat. Dan manakala pengendalian diri pada seseorang terganggu, maka akan timbul berbagai reaksi patologik (kelainan) baik dalam berfikir, alam perasaan, dan prilaku yang bersangkutan. Reaksi patologik yang ditimbulkan tidak saja menimbulkan keluhan subjek pada dirinya, tetapi juga dapat, mengganggu lingkungannya.

Jelaslah bahwa ibadah puasa merupak sarana berlatih diri agar memperoleh manfaatnya yaitu pengendalian diri, tidak hanya makan dan minum saja, melainkan dalam segala bidang kehidupan yang fana ini. Carilah segala kebutuhan dan kesenangan hidup di dunia ini, namun carilah yang halal dan baik, dan jangan berlebih-lebihan.

\section{METODE PENELITIAN BENTUK PENELITIAN}

Sesuai dengan permasalahan penelitian, maka jenis penelitian yang digunakan adalah field research (penelitian lapangan) dengan menggunakan metode kualitatif.Teknik pendeskripsian yang dilakukan sesuai dengan masalah penelitian. Fungsi ibadah puasa dalam membentuk kepribadian remaja akan digali dan di deskripsikan. Pendeskripsian itu berdasarkan data yang diperoleh dari remaja dan informasi dari pihak lain seperti orang tua remaja, para pemuka agama serta warga masyarakat yang memungkinkan dapat memberikan data yang di butuhkan kebenarannya dengan fungsi ibadah puasa Ramadhan dalam membentuk kepribadian remaja Masjid Jami’ Al-Muharram di Desa Bandar Khalipah Dusun I Kecamatan Percut Sei Tuan Kabupaten Deli serdang.

\section{TEKNIK PENGUMPULAN DATA}

Dalam metode penelitian kualitatif, peneliti merupakan instrumen utama (keyinforman). Hakikat peneliti sebagai instrumen kunci diaplikasikan dalam penggunaan teknik pengumpulan data kualitatif yang terdiri dari observasi berperanserta dan wawancara. Menurut Salim dan Syahrum (2010:119) dalam 
bukunya menuliskan bahwa observasi berperan serta adalah pengumpulan data dengan menggunakan observasi berperanserta ditunjukkan untuk mengungkapkan makna suatu kejadian dari setting tertentu, yang merupakan perhataian esensial dalam penelitian kualitatif. Observasi berperanserta dilakukan untuk mengamati obyek penelitian, seperti tempat khusus suatu organisasi, sekelompok orang, atau beberapa aktivitas suatu sekolah.

Menurut Bogdan dan Biklen (2010:119) dalam buku yang ditulis oleh Salim dan Syahrum mengatakan bahwa wawancara ialah percakapan yang bertujuan, biasanya antara dua orang (tetapi kadang-kadang lebih) yang diarahkan oleh salah seorang dengan maksud memperoleh keterangan.

\section{ANALISIS DATA}

Dalam penelitian kualitatif, analisis data secara umum dibagi menjadi tiga tingkat, yaitu analisis data pada tingkat awal, analisis pada saat pengumpulan data lapangan dan analisi data setelah selesai pengumpulan data. Esensi analisis data dalam penelitian kualitatif adalah mereduksi data, karena dalam penelitian kualitatif data yang dikumpulkan harus mendalam dan mencakup sesuai fokus dan tujuan penelitian.

Dalam Arikunto (2006:12) di antara banyak model penelitian kualitatif, yang dikenal di Indonesia adalah penelitian Naturalistik. Dalam pelaksanaanya analisis data kualitatif bertujuan pada proses penggalian makna, penggambaran, penjelasan dan penempatannya pada konteks masing-masing oleh sebab itu, data yang diperoleh harus diorganisir sedemikian rupa dalam struktur yang mudah dipahami dan diuraikan. Dalam penelitian ini teknik analisa data yang penulis gunakan teknik triangulasi data dengan metode 1) Pengumpulan data, 2) Reduksi data, 3) Prediksi simpulan dan Narasi hasil analisis (Arikunto, 2006:213). Dengan pengecekan data antara lain: reliabilitas instrumen atau pedoman pengamatan dan reliabilitas pedoman wawancara.

Analisis data dalam penelitian kualitatif bergerak secara induktif, yaitu data/fakta dikategorikan menuju tingkat abstraksi yang lebih tinggi melakukan sintesis dan mengembangkan teori melalui wawancara dan dokumentasi, maka dilakukan pengelompokan dan pengurangan yang tidak penting. Setelah itu 
dilakukan analisis penguraian dan penarikan kesimpulan tentang Pengalaman Remaja dalam Mengimplementasikan Puasa Sebagai Pembentuk Kepribadian.

\section{HASIL PENELITIAN}

Setelah melakukan wawancara dengan beberapa anggota remaja Masjid Jami’ Al-Muharram yang merupakan informan dalam penelitian ini, maka peneliti memperoleh beberapa pengalaman dari mereka dalam mengimplementasikan puasa sebagai pembentuk kepribadian. Ada pengalaman yang hampir sama dan ada pula yang berbeda. Dimana beberapa pengalaman itu telah peneliti tabelkan yaitu:

\begin{tabular}{|c|c|c|c|}
\hline No & Nama & Umur & Pengalaman \\
\hline 1 & Angga Advori Pratama & 20 & $\begin{array}{c}\text { Puasa berdampak positif terhadap } \\
\text { pembentukan kepribadiannya }\end{array}$ \\
\hline 2 & Anggi Putri Dewi & 18 & $\begin{array}{c}\text { Puasa berdampak positif terhadap } \\
\text { pembentukan kepribadiannya }\end{array}$ \\
\hline 3 & Hermansyah Piliang & 21 & $\begin{array}{c}\text { Puasa belum berdampak apapun terhadap } \\
\text { kepribadiannya }\end{array}$ \\
\hline 4 & Ridwan & 17 & $\begin{array}{c}\text { Belum dapat merasakan hikmah dari } \\
\text { puasa terutama terhadap pembentukan } \\
\text { kepribadiannya }\end{array}$ \\
\hline
\end{tabular}

Dari data di atas dapat dianalisis bahwa pengalaman informan dalam mengimplementasikan puasa sebagai pembentuk kepribadian akan di uraikan secara lebih rinci berdasarkan hasil wawancara. Pertama, berdasarkan wawancara yang dilakukan peneliti Tanggal 25 Maret 2013 Pukul 20.15 WIB dengan saudara Angga Advori Pratama yang akrab disapa dengan panggilan Angga yang saat ini berusia 20 tahun dan sedang kuliah di salah satu perguruan tinggi swasta yang ada di Medan. Beliau sebagai sekretaris Remaja Masjid Jami’ Al-Muharram mengatakan:

Puasa yang saya kerjakan sangat berpengaruh terhadap diri pribadi saya baik itu secara emosi maupun berinteraksi sosial. Di samping itu juga berpengaruh terhadap kepribadian saya karena puasa dapat membentuk kepribadian yang positif dalam diri saya menjadi pribadi yang suka dengan perbuatan yang baik dan lebih mudah bersyukur dengan apa yang saya miliki. Disamping itu puasa juga dapat memberikan contoh sikap-sikap yang baik dalam diri saya. Pada saat 
melaksanakan puasa harus di barengi dengan niat. Niat adalah suatu keyakinan dalam hati untuk melakukan suatu perbuatan. Jadi ketika saya meyakini dengan sungguh-sungguh maka yang terjadi adalah sikap saya untuk melakukannya dengan ikhlas dan yang paling penting adalah melaksanakannya dengan kesadaran beliau sendiri dengan mengharapkan ridho Allah tanpa paksaan dari orang tuanya ataupun karena sesuatu hal yang lain. Karena dari kecil saya sudah terlatih sampai usia dewasa ini sudah mengerti hukum dan syarat-syaratnya. Yaitu wajib jika di bulan Ramadhan, dan sunah jika puasa senin kamis dan puasa sunah lainnya, selain itu saya merasakan perbedaanketika selesai melaksanakan puasa maka hati saya lebih tenang, dapat berfikir dengan jernih, tidak mudah marah, emosi dan nafsu lebih terkendali, dan saya juga merasa lebih sehat selama bulan ramadhan itu karena pola makan lebih teratur. Hal ini berbeda sekali dengan sebelum melaksanakan puasa biasanya saya selalu mudah marah, emosi kurang terkendali dan nafsu selalu menguasai saya. Saya juga merasakan bahwa dengan melaksanakan puasa akan melahirkan ketenangan jiwa, ketenangan jiwa merupakan kunci dalam mencapai kebahagiaan hidup di dunia maupun akhirat. Sementara itu orang yang senantiasa mempunyai jiwa yang tenang maka ia tidak mudah terpancing emosinya, karena setiap persoalan dan permasalahan yang datang akan senantiasa bersandar pada yang Maha Kuasa.

Hal senada juga dikatakan seorang remaja Masjid perempuan bernama Anggi Putri Dewi Nasution (Wawancara Tanggal 26 Maret 2013 Pukul 16.15 WIB) yang pada saat ini sudah berusia 18 tahun dan sekolah di salah satu SMA yang ada di Medan. Anggi merupakan bendahara umum pada remaja Masjid Jami’ Al-Muharram mengatakan :

Puasa sangat berpengaruh besar terhadap kepribadian saya, apalagi dalam berpakaian dan bergaul dengan lawan jenis.Pada saat berusia 15 tahun saya sudah mulai belajar untuk melaksanakan puasa dengan kesadaran sendiri tanpa ada paksaan dari orang tua lagi sampai saat ini.Karena saya sudah merasakan betapa indahnya ketika makan sahur bersama di waktu fajar yang sangat jarang di lakukan, betapa nikmatnya ketika berbuka bersama dengan makanan yang enakenak dan juga jarang di laksanakan.Pada malam harinya selalu sholat tarawih berjamaah dan selesai sholat lanjut dengan tadarusan Al-Qur'an.Begitu banyak 
keunikan-keunikan yang di dapat ketika bulan ramdhan mungkin itulah berkahnya bulan puasa ramadhan bagi saya, dan hal itulah yang membuat saya sangat termotivasi malakukan puasa dengan kesadaran sendiri.

Saiful Anwar Al Batawi (2012:95-98) dalam bukunya menuliskan banyak perbuatan-perbuatan yang harus di jauhi oleh orang yang berpuasa, karena kalau perbuatan ini dilakukan pada siang hari di bulan Ramadhan akan merusak puasanya dan berlipat dosanya. Perkara tersebut adalah: makan dan minum dengan sengaja, muntah dengan sengaja, haidh dan nifas, suntikan yang mengandung makanan, dan berjima.

Bagi saudari Anggi sendiri kepribadian itu adalah jati diri yang ada dalam diri manusia yang teraplikasi dalam berabagai tingkah laku. Setiap prilaku yang lakukan sehari-hari itu akan mencerminkan kepribadiannya. Bagi beliau puasa merupakan salah satu instrument untuk membentuk kepribadian yang berakhlak, berbudi pekerti, dan religious. Alhamdulillah sampai sekarang Anggi selalu berusaha untuk melaksanakan puasa-puasa sunah seperti senin kamis, karena beliau sudah merasakan hikmah dari puasa itu sendiri terhadap perubahan prilakunya.

Selanjutnya, berdasarkan hasil wawancara tanggal 27 Maret 2013 Pukul 21.00 WIB dengan remaja yang bernama Hermansyah Piliang yang saat ini sudah berusia 21 tahun dan tidak bersekolah lagi. Herman merupakan wakil ketua dari remaja Masjid Jami' Al-Muharram. Beliau adalah anak perantauan dari Dairi, hidup sebatang kara dan beliau tinggal di dusun II dengan mengontrak rumah yang ukurannya sedang.

Pengalaman beliau selaku wakil ketua remaja Masjid dalam mengimplementasikan puasa sebagai pembentuk kepribadian mengatakanbahwa puasa memang sangat banyak hikmahnya, akan tetapi saya merasa belum ada dampaknya terhadap kepribadian saya. Selama puasa emosi sayatetap seperti biasa selalu meledak kalau tidak sesuai dengan keinginan saya baik disiang hari maupun malam harinya. Tingkah laku sayajuga tetap seperti biasa sebagaimana sebelum tiba puasa Ramadhan.Yang biasanya saya malas sholat, malas mengaji bahkan tidak pernah dan jujur sampai sekarang pun saya belum lancar dalam mengaji karena saya sekolah hanya tamat SD saja. Kalau malam hari saya juga 
biasa pergi jalan-jalan bersama pacar saya dan yang lebih asyiknya kalau bulan puasa Ramadhan ada namanya asmara subuh yaitu jalan-jalan bersama pacar setelah selesai sholat subuh dan itu pun saya tidak ketinggalan. Artinya bagi saya bulan puasa Ramadhan itu sama saja dengan bulan- bulan yang lainnya walaupun saya tetap menjalankan puasa di bulan Ramadhan.Disini jujur saya katakana bahwa sejauh ini puasa yang saya laksanakan belum pernah jumlahnya penuh selama satu bulan di karenakan saya memang tidak tahan berpuasa kalau tidak makan sahur. Sebenarnya kalau di tanya dari lubuk hati yang paling dalam saya sangat sedih karena tidak bisa melaksanakan puasa penuh satu bulan. Dikarenakan saya tinggal di kontrakan hanya seorang diri, jadi pola makan saya pun tidak teratur. Kadang kala saya masak sendiri, makan sahur sendiri, dan berbuka puasa sendiri, yang sedihnya terkadang saya tidak terbangun untuk sahur karan hanya sendirian sehingga besoknyasaya tidak berpuasa karena tidak tahan lapar.

Kemudian menurut penuturan beliau bahwa dalam melaksanakan puasa Ramadhan selama ini belum dari kesadaran sendiri akan tetapi karena malu pada tetangga, juga karena beliau kurang paham mengenai syarat-syarat dan hukumnya. Disamping itu yang menjadi hambatan bagi beliau adalah karena malu belajar dan minder kepada kawan-kawan, karena jauh dari orang tua menjadi kurang semangat menjalani puasa, banyaknya kawan yang tidak berpuasa dan selalu ngumpul di kontrakannya, beliau segan dan merasa tidak enak kalau di usir sehingga kadang beliau sendiripun jadi ikut membatalkan puasanya karna pengaruh teman-teman.

Beliau juga menjelaskan bahwa usaha yang di lakukannya untuk mengatasi masalah itu belum ada. Alasan beliau adalah karena sibuk bekerja. Kalau sudah pulang kerja nanti sudah capek dan malas mengerjakan apapun dan bahkan sholat pun sering tinggal. Hal-hal seperti inilah yang membuat kepribadian herman tidak bisa stabil karena sangat banyak faktor-faktor yang tidak mendukung di lingkungannya. Terkadang nanti prilakunya sudah baik, rajin sholat ke masjid, dan terkadang pula tidak pernah lagi nampak tidak tau perginya kemana, terkadang beliau juga ikut-ikutan menghisap sabu-sabu, berpacaran, bahkan pernah juga minum-minuman jika ada pesta. Beliau juga mengatakan sebenarnya dia sendiri tidak mau seperti itu, akan tetapi lingkungan lah yang 
merubah setiap prilakunya dan juga karena tidak ada perhatian dari orang tua dan dari orang- orang yang di sayanginya.

Sejalan dengan permasalahan yang di alami saudara Herman diatas maka informan yang keempat adalah bernama Ridwan Nasution yang saat ini sudah berusia 17 tahun dan sedang sekolah si salah satu SMA Negeri yang ada di Medan. Berdasarkan penuturan beliau pada saat saya wawancara Tanggal 28 Maret 2013 Pukul 20.15 WIB di Masjid Jami’ Al-Muharran beliau mengatakan bahwa kalau bulan Ramadhan tiba kebiasaan saya adalah lebih banyak tidur dan main game dari pada melakukan pekerjaan seperti membantu orang tua, karena orang tua saya sendiri pun sibuk dengan pekerjaaan mereka masing- masing. Kalau di malam hari saya lebih banyak keluyuran dengan teman-teman saya sampai larut malam dari pada sholat tarawih dan tadarusan.Saya malas tadarus karena saya kurang pandai membaca Al-Qur'an dan tidak menguasai tajwidnya makanya saya lebih memilih untuk bermain-main. Kalau di tanya masalah sholat ya sering dan bayak yang ketinggalan. Bagi saya bulan Ramadhan itu uniknya adalah ketika berbuka puasa bersama disana itu sangat banyak makanan yang enak-enak dan kebiasaan saya adalah makan sekenyang-kenyangnya sehingga malas untuk pergi sholat tarawih.Sebenarnya ketika berpuasa pun saya sering membatalkannya diam-diam karena tidak tahan lapar.Terkadang saya juga ukitikutan taruhan main bola apalagi yang main adalah klub sepak bola favorit saya.Jadi dampak yang saya rasakan dari puasa Ramadhan terhadap pembentukan kepribadian saya ya tidak ada. Prilaku saya sama saja baik bulan puasa maupun bulan yang lainnya.

Dari penuturan beliau di atas dapat di analisis bahwa pengalam beliau setelah melaksanakan puasa Ramdhan sama sekali tidak ada dampaknya. Bagi beliau sama saja bulan puasa Ramadhan dengan bulan yang lainnya. Pada hal Rasulullah sendiri yang mengatakan bahwa bulan puasa Ramadahn itu lebih baik dari pada seribu bulan seandainya kamu mengetahui. Tentunya hal ini bisa terjadi di karenakan pengetahuannya yang kurang tentang agama khususunya tentang puasa. Beliau yang masih berumur 17 tahun mengatakan sudah lupa tentang apa hukum dan syarat- syarat berpuasa. Padahal disaat-saat remaja seperti inilah ilmu itu harus di ketahui seluas-luasnya.Hal ini tentu tidak lepas dari dukungan dan 
perhatian orang tua. Tapi sayangnya orang tua saudara Ridwan yang terlalu sibuk dengan pekerjaan mereka masing-masing terlupa untuk memperhatikan perkembangan anaknya. Hal ini membuat beliau bertingkah sesuka hatinya karena kurang kasih sayang dan perhatian dari orang-orang disekitarnya. Beliau juga selalu menurutkan hawa nafsunya untuk memenuhi keinginannya, kurang bersabar sehingga belum bisa untuk bertanggung jawab dalam menunaikan kewajibannya.

Sementara itu informasi dari hasil wawancara Tanggal 29 Maret 2013 Pukul 16.10 WIB yang penulis lakukan dengan pemuka agama Drs.H. Aswan Lubissebagai sumber data sekunder mengatakan bahwa Puasa itu berpengaruh besar dalam membentuk kepribadian seseorang khususnya bagi para remaja. Dan puasa itu sebagai benteng bagi remaja untuk selalu berfikiran yang positif dalam mengahadapi segala bentuk permasalahan dan perkembangan teknologi yang ada pada saat ini.Puasa merupakan salah satu bentuk dari bukti keimanan seseorang kepada Allah, iman itu sendiri merupakan sesuatu yang akan mengarahkan dan membentuk prilaku seseorang, baik ketika ia berinteraksi dengan Tuhannya, diri sendiri maupun orang lain. Dalam memenuhi kebutuhan spiritual untuk mewujudkan kepribadian yang mantap dan akhirnya melahirkan mental yang sehat, maka puasa yang dilaksanakan dengan sepenuh hati dan niat yang ikhlas semata mengharap ridhonya Allah akan membentuk fisik dan mental yang kuat dan pada akhirnya akan melahirkan pribadi-pribadi yang mantap.

Kepribadian yang mantap yaitu orang yang senantiasa stabil prilakunya. Semua ucapan maupun perbuatannya sesuai dengan ajaran yang ditetapkan oleh Allah SWT.Manusia yang berkpribadian mantap merupakan orang yang memiliki an-nafsul muthma'innah. Yaitu orang-orang yang hidup berdasarkan fitrah yang telah dibawanya sejak lahir.

Tentu saja fitrah ini membutuhkan sesuatu yang bisa memeliharanya maupun sesuatu yang mampu membuatnya tumbuh lebih baik dan mampu melawan hawa nafsu, menjauhkan diri dari perbuatan yang maksiat serta menjauhkannya dari godaan-godaan baik yang datangnya dari dalam maupun dari luar dirinya. 
Disinilah peranan puasa dalam membina dan membentuk kepribadian seseorang khususnya para remaja, disamping iman dan taqwa kepada Allah maka puasa merupakan salah satu alat untuk menjaga dan memelihara fitrah yang dibawa seseorang sejak lahir sehingga menjadi benteng bagi diri remaja agara selalu terhindar dari perbuatan-perbuatan yang maksiat serta godaan-godaan yang datang dari dalam dirinya maupun dari lingkungan dimana ia tinggal.

\section{KESIMPULAN DAN SARAN KESIMPULAN}

Dari hasil penelitian yang penulis lakukan di kalangan remaja, pemuka agama, masyarakat dan orang tua remaja yang ada di desa Bandar Khalipah Kecamatan Percut Sei Tuan Kabupaten Deli Serdang bahwa ada hubungan antara pelaksanaan ibadah puasa Ramadhan pada khususnya dan puasa-puasa sunah pada umumnya dengan pembentukan kepribadian remaja, ini terlihat dari tingkah laku yang ditampilkan remaja dalam kehidupan di masyarakat. Bagi remaja yang melaksanakan puasa dengan sungguh-sungguh, cara berpakaian mereka sopan dan tidak bertentangan dengan ajaran agama Islam. Mereka juga tidak ikut berjudi, mengkonsumsi narkoba, pergaulan bebas, mencuri dan prilaku negatif lainnya.

\section{SARAN}

Disarankan kepada para remaja agar meningkatkan pengetahuan dan pemahamannya akan agama khususnya tentang ibadah puasa, karena dengan kita melaksanakan puasa akan terhindar dari berbagai penyakit, akan menyehatkan mental kita, menumbuhkan rasa sabar, seingga terhindar dari perbuatan keji dan munkar, serta dapat membentuk kepribadian yang sejati. Kemudian bagi peneliti selanjutnya hasil penelitian ini dapat dikembangkan sesuai dengan kebutuhan permasalahan yang akan di teliti selanjutnya.

\section{DAFTAR PUSTAKA}

Amin, Samsul Munir. Bimbingan dan Konseling Islam. Jakarta : Amzah, 2010.

Arikunto, Suharsumi. Prosedur Penelitian Suatu Pendekatan Praktik. Jakarta: Rineka Cipta, 2006.

Aziz, Nazaruddin. Puasa Untuk Bertaqwa. Surabaya: Al-Ikhlas, 1978.

Az-Zahrani, Musfir bin Said.Konseling Terapi. Jakarta: Gema Insani Press, 2005. 
Al-Batawy, Saiful Anwar.Kesalahan Fatal Dalam Berpuasa. Jakarta: Kunci Imam, 2009.

Daradjat, Zakiah. Kesehatan Mental. Jakarta: Gunung Agung. 1995

Hawari, Dadang. Ilmu Kedokteran Jiwa dan Kesehatan Jiwa. Jakarta: Dana Bakti Prima Yasa, 1996.

Jalaluddin.Psikologi Agama. Jakarta: Rajawali Perss. 2010.

Metia, Cut. Psikologi Kepribadian. Bandung: Cita Pustaka Media Perintis, 2009.

Al-Mighwar, Muhammad.Psikologi Remaja. Bandung: Pustaka Setia, 2006.

Minarno, Eko Budi. Gizi dan KesehatanPerspektif Al-qur'an dan Sains. Malang: UIN-Malang Press, 2008.

Muhammad. Pendekatan Kesehatan Terhadap Ibadah Puasa. Surabaya: AlIkhlas, 1980.

Muhsin, Akhyar As-Shiddiq dan Dahlan Darmawisata. Dahsyatnya Puasa Wajib Dan Sunah (Solusi Sehat, Sukses, dan Bahagia).Jakarta selatan: Qultum Media, 2010.

Nafi, Dian. Fiqih Puasa Untuk Remaja. Jakarta Timur: Inti Media, 2010.

Najati, Muhammad Utsman. Psikologi Dalam Al-Qur'an (Terapi Qur'ani Dalam Penyembuhan Gangguan Kejiwaan. Badung : Pustaka Setia, 2005.

Rif'an, Ahmad Rifa'i. Izrail Bilang Ini Ramadhan Terakhirku. Jakarta: Republika. 2010.

Salim, Ahmad Husain Ali.Menyembuhkan Penyakit Jiwa \& Fisik. Jakarta: Gema Insani. 2009. 